\title{
Visualising Shattered Lives: Potentiality in Representations of Rape Victimisation in Contemporary Japanese Cinema
}
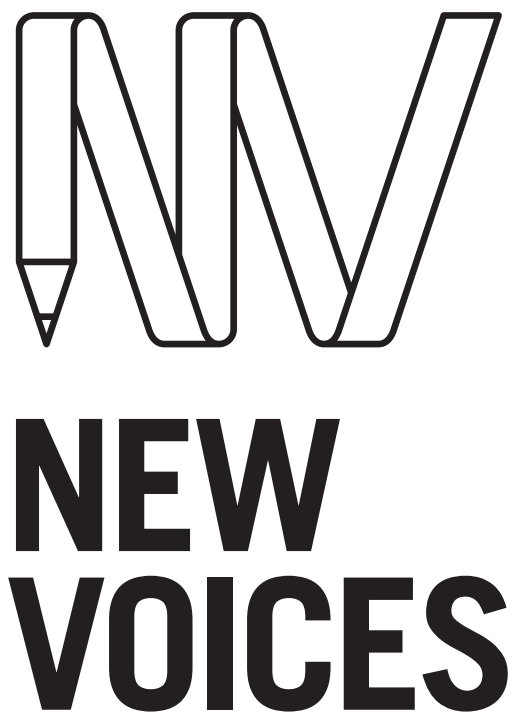

IN JAPANESE STUDIES

\section{HEI-LEI CHENG}

Australian National University

\section{ABSTRACT}

This article examines how cinematic representations of rape can challenge the silence which surrounds the issue of rape and sexual violence in Japan. A textual analysis of two contemporary fictional Japanese films, DV: Domestic Violence [2005] and The Ravine of Goodbye [2013], was performed to illustrate how filmmakers can use narrative and cinematographic techniques to influence the viewer to reflect upon their attitudes to rape and rape victims. By examining how these two films depict rape and rape recovery, this article argues that there is discursive potential inherent within cinema to shape our imaginations and ideals about the world. But while the filmmaker can construct rape representations that encourage reflection, how the viewer decides to engage with the film has bearing on whether this potential for reflection is realised.

\section{KEYWORDS}

cinema; criminality; domestic violence; film; gender; rape; representation; women; sexual violence; spectatorship

\section{JAPANFOUNDATION 8 \\ BRINGING JAPAN TO YOU \\ To link to this article: \\ http://dx.doi.org/10.21159/nvjs.08.04}

ISSN 2205-3166

New Voices in Japanese Studies is an interdisciplinary, peer-reviewed journal showcasing the work of emerging scholars from Australia and New Zealand with research interests in Japan.

All articles can be downloaded free at $\underline{\text { newvoices.org.au }}$

(c) The Japan Foundation, Sydney and Hei-Lei Cheng, 2016

\section{(c) $(9)$}

This work is licensed under a Creative Commons Attribution-NonCommercialNoDerivatives 4.0 International License. 


\section{INTRODUCTION}

Stories have a remarkable power to influence and transform a viewer's realworld beliefs while immersing them in a fictional context. From stories, we pick up ideas and ideals about the world and our place within it; through stories, we spread these ideas and ideals into the world. This article explores how representations of rape in film can potentially encourage a shift in the way that individuals perceive sexual violence. Using a textual analysis of two contemporary fictional Japanese films, DV: Domestic Violence [DV:ドメステ イック・バイオレンス; 2005] and The Ravine of Goodbye [さよなら渓谷; 2013], I argue that cinematic representations of rape and rape recovery can help break the relative silence around rape in Japan. Films that represent the issue of sexual violence with the necessary sensitivity can help deepen viewers' understandings of this issue and build empathy in society for rape victims. This article specifically examines representations of female victims of male perpetrated rape; while other forms of sexual violence-such as female-onmale rape, female-on-female rape and male-on-male rape-are also depicted in Japanese cinema, discussion of these representations is beyond the scope of this article.

Representations of rape in popular culture is a topic that has fuelled divisive discussions and strong reactions within public and academic circles. In recent years, increasing numbers of feminist commentators have discussed the issue, concentrating primarily on two main points: 1) the prevalence of sexual violence in popular culture media, and 2) the nature of these depictions. Their concerns are with how the ubiquity of rape representations has naturalised images of sexual violence against women within the general populace (Higgins and Silver 1991; Projansky 2001). While professional critics are also active in this area, the bulk of the commentary comes increasingly from grassroots feminists writing on mass media and popular culture. In English-speaking nations, the emergence of websites and communities such as The Mary Sue and Bitch Media has offered women a space to express anger and frustration at stereotypical depictions of rape and sexual violence, and to call for more accurate and diverse representations. These criticisms are largely based on their own personal experiences. Utilising the internet to make their voices heard, their conversations spread rapidly into the general public and extend beyond a discussion of popular culture to pose broader questions about sexual violence in society.

In Japanese society, however, there is noticeably less critical engagement with rape representation in popular culture media, and the resulting discussion on the broader problem of sexual violence is also absent. I hope that engaging with such representations can help to facilitate important conversations on the topic of sexual violence in Japan, as well as broader discussion on popular culture and its role in motivating social change. By examining how cinematic depictions of the realities of rape and rape recovery can stimulate empathy for rape victims, I will discuss two key points crucial for this transformative potential to be realised: 1) how the filmmaker depicts rape and its aftermath, and 2) whether the viewer chooses to critically respond to the discursive potential in the text.

$$
\text { potentialin the text. }
$$




\section{Japan and Sexual Violence}

Firstly, it is important to understand the culture of silence that surrounds the issue of sexual violence within Japanese society. Between 2011 and 2015, the number of reported cases of rape each year was under 1,500 (NPA 2016, 5). However, research suggests that the actual statistics are much higher, as many victims do not officially seek help or report the crime. In a survey by the Gender Equality Bureau Cabinet Office (2014), 67.5\% of participants who identified themselves as rape victims did not consult anyone after their attack. In Japan, victims do not report rape for a number of reasons, including fear of threats and further violence from the perpetrator, feelings of embarrassment and shame, and the belief that discussing the attack is pointless (Burns 2005; Gender Equality Bureau Cabinet Office 2014). Although government services and women's groups continue to raise public awareness of services available for rape victims and encourage victims to seek official support, victims' reluctance to report rape contributes to the culture of silence that surrounds sexual violence at an individual and societal level (Buckley 1997; Burns 2005; Kaino 2005; Sawada 2010).

Furthermore, feminists and human rights activists have criticised Japan's laws around rape for the rigid barriers it puts before victims seeking legal justice. In her examination of rape court cases in Japan, Catherine Burns (2005) argues that cases are treated differently depending on the characteristics of the attack. Cases that conform to dominant perceptions of rape, such as stranger rape, are seen as " $t s \bar{u} j \overline{0}$ " (通常; regular), and are more likely to achieve a successful prosecution $(2005$, 4). However, cases that do not fit this perception, such as acquaintance rape or marital rape, are considered “fushizen” (不自然; abnormal, unacceptable) and are "consistently distrusted, dismissed or not heard at all" $(2005,4)$. By not conforming to the stereotype of "tsūjō" rape, these latter types of cases place victims' personal lives under greater scrutiny, and the burden of proving violence and sufficient resistance to the attack is much higher (Burns 2005; Yatagawa and Nakano 2008; Asatori and Suzuki 2009). This practice in the Japanese criminal justice system can deter victims from reporting their attack.

While the Japanese legal system has established rape as a criminal wrong and it is also socially recognised as such, silence still surrounds the issue. This is due largely to the following three factors. First, the construction of male sexuality as a natural biological response is used as a rationale to avoid treating rape as a serious social issue. The male body was first likened to a machine by the state in the early Meiji period [1868-1912], and in line with this, sexual gratification was established as a natural impulse and a means to "maintain proper functioning" (McLelland 2005, 36). Takako Konishi (2009) argues that "because rape is still generally accepted as an extension of normal sexual activity, the violence of rape is made invisible” (強姦が通常の性交の延 長にあると考える社会通念のために、行為の暴力性が見えなくなってしまうのであ る。) (81). ${ }^{1}$

Second, sexual relations are generally treated as a private issue within Japanese society's public/private dichotomy. Burns (2005) argues that the

1 All English translations of Japanese source text are by the author. 
construction of "male sexuality" as "natural" in Japan thus "serves to orient male sexual practices in general as private and, therefore, beyond regulation" (54). Although criminalised in the penal code and prosecutable by the state, rape tends to be treated as a private matter (2005). Third, Japan's patriarchal power structure continues to prevent sexual violence from being treated with sufficient gravity. In a patriarchal society that binds women to their roles as wives and mothers, a married woman is considered her husband's possession; any forced sexual relations thus tend to be tied to notions of obligation and wifely duty (Tsunoda 1995). Japan's existing domestic violence law represents an attempt to balance the husband-wife relationship; however, the psychological, sexual, social and financial control that husbands can have over their wives is still often overlooked in domestic abuse cases (Kaino 2010). Burns (2005) argues that Japanese law continues to frame rape as "an injury against the property rights of husbands or fathers and, thus, the patriarchal order", thereby contending that the rape law's true intention is the protection of chastity rather than women's human rights (69). Japanese feminists continue to fight against such traditional gender notions faced by rape victims in the criminal justice system (AJWRC 2008).

These three dynamics are embedded within and reinforced by institutional structures and cultural practices that are built around male power and privilege. They ensure that silence continues to surround rape as an issue within social and political discourse, acting as a suffocating barrier to keep victims of sexual violence from speaking out. Masayo Niwa (2004) points to the Super Free scandal of 2003 as evidence for how "[Japanese] society continues to exert tremendous pressure on victims of sexual violence to remain silent" (1). Members of an all-male student group called 'Super Free'2 used events to scout potential rape victims: once their victims were drunk and unable to resist, they were lured away then raped by club members, and photos were taken to stop victims from speaking out. With the fear of blackmail, only three out of the hundreds of suspected victims stepped forward to report the crimes committed against them.

But media coverage of the Super Free incident shows that it is possible to break through this culture of silence: the public discourse it generated prompted twelve more women to come forward following the arrests (Cybriwsky 2011). The success of the feminist movement in challenging dominant social norms of silence around domestic violence is further evidence of how 'taboo' subjects can change through public exposure. After a decade of advocacy and political mobilisation, Japanese women's groups successfully lobbied the government to introduce a law against domestic violence in 2001. Their achievement encouraged survivors to share their own experiences so that the law could be revised to include common-law couples and ex-spouses, showing that grassroots women's movements can bring about policy change in Japan (Shin 2011).

However, despite progress in the legal sphere, fictional representations of rape and sexual violence continue to inundate Japanese popular culture. This is

2 Super Free was a student group that promoted rave events in Tokyo nightclubs and was initially based in Waseda University. Its popularity saw the group expand to include students from other prestigious Tokyo universities, becoming an inter-university club with 30 members.

Hei-Lei Cheng New Voices in Japanese Studies, Vol. 8, 2016, pp. 77-97 
not a condition unique to Japan, as such scenes have become a normalised narrative device across numerous entertainment industries (Smith 2004; Heller-Nicholas 2011). For example, within the Japanese film industry, sexual violence is popular in the softcore pornographic 'pinku eiga' (ピンク映画; lit., 'pink films') genre, which emerged in the 1960s. As Jack Hunter (1998) argues, these films have a formulaic style where the "women ... fall in love with their rapists, and end up begging for more", leaving an impression that these films condone rape (81). Since the 1980s, these rape scenes have been "slowly phased out" of pink films due to cultural awareness and attempts to draw a female audience (Arnold 2015, 36). With other subgenres of pornography, however, the rape of young women remains a mainstay of the industry (Arnold 2015). Further, with the internet now allowing greater access to pornography, the diffusion and consumption of graphic imagery of sexual violence has dramatically increased over the past two decades (Omori et al. 2011). In many of these representations, women are depicted as "sexually materialised object[s] ready to be exploited (like a disposable toy) exclusively as a means to produce sexual gratification" for a primarily male viewership (Shibata 2008, 2). Feminist media critics vociferously oppose representations of this nature; instead, they call for sensitive representations that can effectively counteract the problematic representations that dominate and influence perceptions about rape and rape victims.

\title{
The Transformative Potential of Cultural Representations
}

The theoretical foundation underlying this article is the idea that all knowledge is constructed. The acquisition of knowledge and our understanding of the world is a dynamic process, which is ever-changing as individuals interact with the world as it changes around them:

\begin{abstract}
Knowledge is socially constructed; knowledge and the knower are interdependent; and all knowledge and knowing are embedded within history, context, culture, language, experience, and understanding [...]. We continually interpret our experiences and interpret our interpretations. And, as such, what we create (e.g., knowledge) is fluid, continually evolving, shifting, broadening, and changing. Thus, there is no finality to our knowledge-our meanings, understandings, or realities. What we create, we create with each other.
\end{abstract}

(Anderson 2007, 8-9)

Our engagement with entertainment opens us to popular culture's ability to either reinforce our existing values and beliefs or to challenge and transform them. It is therefore important to understand the processes and dynamics that work to shape our perspectives on the world, the people in it, and ourselves.

Mass media, through which representations are disseminated across a wide audience, have emerged as crucial social institutions involved in shaping public consciousness. As cultural artefacts, films provide a window into the values, beliefs and attitudes entrenched within a nation's cultural and social history. Stuart Hall (1980) argues that all messages have a dominant or preferred 
meaning encoded into them, and that these often reflect dominant ideological discourses. Thus, the constant repetition of certain messages and imagery in mass media serves to normalise and reinforce behaviours and ideas. So when rape narratives are used in popular culture, they can "reinforce certain social patterns and trends and invalidate others" (Durham 2008, 148).

However, within mass media there are always competing voices and alternative perspectives that resist hegemonic ideologies. As media production and consumption increases, media representations have become sites where users can access alternative viewpoints that contribute to generating change (Halberstam 1993; Fuentes 2013). By constructing gendered stories of sexual violence from different perspectives, there is a denial of pleasure to the dominant version of the male heterosexual gaze (Fuentes 2013). Rape representations that resist conventional portrayals of rape have the potential to "destabilise the real" by reorienting our perceptions regarding rape and rape victims (Halberstam 1993, 199). From this potential to transform the collective imagination emerges the potential to induce change.

\section{Women Engaging with Rape Representations}

Key to this article's direction is Sarah Projansky's book Watching Rape (2001), which explores rape representations within American film and television since the 1980s. Projansky argues that feminists are faced with a conundrum born of "a desire to 'end' rape and a need to 'represent' (and therefore perpetuate discursive) rape in order to challenge it" (19). That is, rape depictions can initiate discourse but still inevitably "contribute to the existence of violence against women in media culture" $(2001,96)$. The argument put forward in this paper is also caught in this dilemma: for cinema to serve as a potential site for activism against rape, the female body must first be victimised to generate activist discourse. Projansky recognises that rape representations can include feminist depictions of rape which "provide an opportunity for reading the representation of rape in ways that have the potential to empower characters and/or spectators rather than ... to increase their experience of vulnerability" $(2001,61)$. While she focuses more on aspects that "seek to recuperate or undermine that empowerment" (2001, 61), I concentrate on the opposite. That is, I argue that although these disempowering elements do exist, nuanced representations of rape can encourage critical discussion about sexual violence within the general public.

This article is also guided by a question raised by Eva Maria Koopman's (2010) research on the ethics of representing and reading rape in literature. Koopman (2010) argues that "representations of seemingly individual suffering and violence can bring to the fore disturbing ethical issues and thus need to be read in an openness to being ethically unsettled" (11). The issue she poses is, "under which conditions, if at all, [is] representing the suffering of others ... possible and desirable" $(2010,13)$ ? Koopman argues that "depicting an immoral act is not in itself immoral, it is the way that the immoral act is represented that matters" $(2010,110)$, a point that will be threaded throughout this article. 
For feminists on the production side of popular culture media, the issue of how to depict sexual violence in a manner that does not (re)traumatise their audience is a constant question. With any fictional work, the intended response is not always elicited and so it can be difficult, if not impossible, to have a rape scene that does not trigger an uncomfortable visceral response in rape survivors, as well as in those who have not experienced rape (Chris 2013). Although this is not true of all survivors, there are some who recognise that sexual violence should not be exempt from artistic expression; it just needs to be represented with more sensitivity (Friedman 2014).

Increasingly, feminist media critics are using digital platforms such as social media and online forums to interrogate pervasive representations of rape within popular culture. Major criticisms include the excessive number of gratuitous rape depictions, their frequent use as devices to shock audiences, and minimal screen time given to exploring the impact of rape on victims as well as their long healing process (Goerke 2013; Friedman 2014; Rodriguez 2014; Myrick 2014; Phillips 2016). It is also important that some of these voices are also the voices of victims asserting their dissatisfaction. Feminist backlash towards violent sexual imagery demonstrates how the encoding/decoding of message "may not be perfectly symmetrical" (Hall 1980, 54). That is, although media makers intend for a specific idea to be received, audiences are not passive consumers of media messages and can respond differently depending on their degree of identification with the maker's point of view. Using the internet to express their opinions and facilitate dialogue on sexual violence, feminist voices in the digital sphere continue to expand their influence and are becoming a voice that the entertainment industry cannot ignore.

\section{BEARING WITNESS: THE RAPE SCENE AND THE VIEWER}

While most people shy away from viewing violence in real life, audiences willingly expose themselves to acts of factual and fictional violence in the consumption of news and popular culture. As representations of immoral and illegal acts, rape scenes in popular fiction films raise a range of ethical issues. When presented with a cinematic rape sequence, the viewer is invited to partake in a spectacle of pain and suffering, both physical and mental. As viewers of these representations, they take on the role of witness and are presented with an ethical dilemma: how can one be entertained and take pleasure from viewing images of suffering?

First, an awareness of fictionality allows the viewer to distance themselves from their involvement in viewing violent acts (Aaron 2007). Furthermore, the viewer can seek to justify being entertained by these acts when they are then shown to be condemned or punished, placing both film and viewer in moral, social and legal alignment (2007). Although the viewer may choose to avoid or ignore this ethical quandary, as Michele Aaron (2007) argues, the imagined suffering of others is "something [the audience is] always implicated in, not only as consumers but as consensual parties in the generation of characters' suffering for our entertainment" (112). This 
involvement, along with the desensitising effect of continual exposure to violent imagery, ${ }^{3}$ produces a state of indifference to images of suffering. The question thus turns towards the conditions that can provoke viewers into becoming active spectators critically and ethically engaging with the text and the subject of rape.

\section{An Unsettling View: Closing the Distance between Screen and Spectator}

Hidden within the processes of production and consumption is a complex, dynamic array of interactions between spectator and a cinematic text. By viewing representations on the screen, the viewer becomes a willing participant to engaging with the text and its producers, creating an implicit contract between spectator and spectacle (Aaron 2007). The viewer's agreement to this unspoken contract becomes unstable as the subject matter begins to challenge social sensibilities. Being entertained by watching depictions of violent acts can possibly place the spectator in an uncomfortable position of moral reflection. With rape representations, the sexual element adds to the dilemma of being a spectator to depictions of violence. As Tanya Horeck (2004) asks in her analysis of rape and spectatorship, "Are we bearing witness to a terrible crime or are we participating in shameful voyeuristic activity?" (vi). As a witness, the spectator is allowed some measure of innocence in their position as bystander; in contrast, the voyeur spies from a distance, potentially gaining sexual pleasure from their watching (Wilson 2012).

Voyeuristic pleasure gained from fictional scenes of violence is grounded in the knowledge of being a safe distance away from the represented experience of suffering. In the case of sexual violence, the potential for the voyeur to experience sexual pleasure is increased. Cinema's fascination with the human form lets the male spectator gaze upon and gain sexual pleasure from the female body: women, put on display for the enjoyment of men, are a spectacle objectified through the male gaze (Mulvey 1989). Female bodies thus become "sites for invasion, penetration, and are often presented in a voyeuristic manner" (Viteo 2012, 15). Within this context, privileging the rapist's point of view could potentially steer the spectator toward identifying with the rapist's perspective. Koopman (2010) argues that this can produce a voyeuristic desire to "see [more], wanting to indulge in the sexual violence from the safe position of the spectator" (18). While voyeuristic pleasure is a socially undesirable affective response to rape representation, this may induce ethical self-reflection if the spectator then becomes ashamed of their initial reaction. If guided to consider that their "internal feeling about a scene [is] abnormal", the spectator's shame can outweigh their sense of pleasure, leading them to focus on more socially acceptable emotions and a contemplation of their spectatorial role (Cartwright 2008). 
In The Ravine of Goodbye [さよなら渓谷; 2013], director Tatsushi Ōmori unsettles the viewer by drawing attention to their position as spectator of a sexual assault, contrasting the viewer's spectatorial position with that of another character in the room. Based on Shūichi Yoshida's 2008 novel of the same name, The Ravine of Goodbye is a story about the repercussions of a gang rape on the victim and one of the perpetrators. At the heart of the film is the relationship between a couple, Shunsuke and Kanako Ozaki, who are neighbours of a mother accused of murdering her child. When a reporter, Watanabe, investigates a tip that Shunsuke was having an affair with the accused, he discovers that Shunsuke was involved in the gang rape of a girl, Natsumi Mizutani, during his university years. Following many misfortunes, she has since disappeared. Eventually, it is revealed that Natsumi is in fact Kanako. Struggling to escape her past, Natsumi met Shunsuke after many years, and following a turbulent struggle with anger and guilt, the two reinvented themselves as husband and wife in a small town.

The film uses a flashback to show the gang rape that shadows Kanako and Shunsuke's relationship. Watanabe is investigating at the university when the scene dissolves to the past, where a young woman and three young men are talking next to a pile of empty beer cans in a clubhouse room. As the camera slowly tracks closer to the jovial group, a couple quietly talking is brought into the shot. When the young woman from the group excuses herself momentarily, the camera reorients to focus on the couple, Natsumi and the young man. The camera lingers on the two's quiet moment before the boisterous trio intrudes. After a moment of play fighting between the men, the camera cuts away from the group to the young woman returning into the clubroom doorway. From offscreen, a male voice rings out, telling the others "hold her down" (ちゃんと抑えて) (00:51:58). Seeing this, the young woman quietly slips away. The camera remains steady on the empty doorway after she leaves the scene, while Natsumi's screams of protest continuing to ring out. Surrounded by the four boys, only her legs can be seen as her shrieks cut across the rowdiness of the boys and the crescendo of the haunting background music.

Director Ōmori guides the viewer to focus on Natsumi's suffering and victimisation whilst trying to avoid evoking voyeuristic pleasures by presenting, unambiguously, the scene as a rape. By emphasising her nonconsent and the boys' use of force, he emphasises the violence and pain of rape rather than the sexual aspects. The viewer is manoeuvred to a crossroad where they can choose to end these images of suffering (by stopping or walking out of the film) or to endure them. The first choice ends the unspoken contract between the viewer and the text, as the viewer no longer consents to viewing the images being shown. The latter choice leads the spectator to the role of witness, a position where they might choose to confront the issue of deriving pleasure from images of suffering. Like the woman who left the scene, the viewer is a witness and bystander to this fictional rape; unlike the woman, who is able to leave and end her role as witness in the film, the viewer cannot do so if they choose to watch the film to its completion. For the viewer that chooses to continue watching, Ōmori creates an uncomfortable atmosphere by prolonging Natsumi's screams as the camera lingers on the empty doorway 
that they cannot leave through. As they watch her struggle, the viewer is invited to reflect on the victimisation and suffering being played out before them.

However, there are limitations to the extent to which the spectator can empathetically understand the traumatised other: being only witnesses to fictionalised representations of sexual violence, spectators cannot truly understand the experience of suffering. Referring to war photography, Susan Sontag (2003) writes that those "who have never experienced anything like what [people affected by war] went through don't understand ... we truly can't imagine what it was like" (126). Empathy, with respect for the experience of those that have suffered, is a desirable response. Yet, the exact experience of another's suffering cannot truly be understood.

A cinematic rape sequence involves considerations from both the producers and the consumers of these representations. For filmmakers, what and how to represent can heavily influence the viewer's response to a rape scene. Uncompromising depictions of sexual violence can guide the viewer to an unsettling ethical position where the victim's suffering becomes etched in their minds and their awareness of their own role as witness is heightened. By closing the distance between the viewer and images of suffering, the filmmaker can trigger self-reflective spectatorship. But while they can attempt to manoeuvre the viewer away from socially undesirable reactions through their directional choices, it is ultimately up to the individual viewer to transition from ethical reflection to social action.

\section{EXPOSING THE SILENCE: THE VICTIM AND EVERYONE ELSE}

In a media-rich environment, cultural representations of the everyday are an oft-inescapable thread woven into the fabric of daily life. Shaped by the society and culture in which they are reproduced, representations are constructions of reality (Hall 1997). As such, fictional films can serve as carefully crafted windows through which the audience is directed to view and become involved in specific experiences, and are a useful avenue for filmmakers to communicate certain messages. By embedding a message within the cinematic narrative, filmmakers can use these spaces for overt or subtle social commentary while still providing entertainment to viewers.

\section{Exploring Representations of Secondary Victimisation}

From first responders to providers of recovery services, there are various avenues for victims of sexual violence to turn to for assistance. Victims are not always able to find help from these agencies, however, and may even be subjected to further victimisation and trauma. This is known as 'secondary victimisation' (Campbell 2005). In DV: Domestic Violence [DV : ドメステイック・ バイオレンス; 2005], director Shun Nakahara draws attention to the poor support services in place for domestic violence victims. DV: Domestic Violence is 
about the increasingly violent marriage between two characters, Shōgo and Yasuko. The marriage begins its downward spiral when Yasuko does not keep her promise to quit her job and become a housewife. The escalation of physical, psychological and sexual abuse that follows results in Yasuko seeking a way out of the situation.

DV: Domestic Violence presents two rape scenes as part of the escalation of violence in Shōgo and Yasuko's marriage. The first occurs after Shōgo sets up a schedule of tasks, including arranging nights for sex. One night when Yasuko is sick, Shōgo insists on following the calendar and having sex regardless (00:25:35). Coughing throughout the ordeal, the camera repeatedly focuses on Yasuko's pained face as she continues to tell him to stop (ちょっ…やめて) (00:25:51) and that it hurts (痛い) (00:26:35). The second rape scene occurs after Yasuko has been forced to quit her job and has endured weeks of abuse. In this scene, Yasuko's non-consent is not voiced but demonstrated through her body language. When Shōgo tells Yasuko to be vocally expressive (声出 せ、声出せ), she remains silent (00:37:52). Yasuko is lifeless as Shōgo lifts up her limbs and her body for leverage. She is completely unresponsive, both physically and vocally. The timeline is unclear but this is likely another of Shōgo's scheduled sessions. Her lack of response and resistance indicates that this is one of many unwanted sexual incidents within the marriage.

The film also represents Yasuko's struggles with various institutions, and the viewer is positioned to contemplate the realities faced by victims trying to seek help, as well as the role that society plays in a rape victim's recovery. Nakahara was motivated to make the film following Japan's introduction of domestic violence laws in 2001. He recognised that "regardless of how well-intended the law is, if people do not properly enforce it then the law means nothing" (どん なに立派な法律でも、それを運用する人たちがしっかりしてくれなければ、何の意 味もありません), and made the scenes between Yasuko and support providers, discussed below, as “a message to people working in public institutions" (公 的機関に携わる人たちへのメッセージ) (Iijima 2012). This sentiment is clearly conveyed in the film.

Yasuko's interaction with law enforcement in the film is a good example of how cinema can serve as a space for social commentary. Following a beating by her husband, Yasuko escapes to a police station for assistance. In the conversation between Yasuko and the policeman, the viewer is shown how the domestic violence law as it was intended is not necessarily applied in reality. The policeman is sympathetic but reluctant to intervene in the situation:

Policeman: Well, the police can't really get involved in domestic matter like this. A family matter really ought to be solved at home.

Yasuko: What about the domestic violence law? ${ }^{4}$

(00:50:50)

As it becomes clear that the officer considers that personal matters within marriage are too 'minor' for the criminal justice system, the officer then 
presses Yasuko further, asking how often her husband has beaten her. After responding that it has been a daily occurrence over the past three months, the officer asks her why this has occurred.

P: There has to be a reason for him to beat you.

Y: The reasons are extremely trivial matters.

P: It may just be you that thinks that. ${ }^{5}$

$(00: 51: 28)$

The policeman's prodding stuns Yasuko. When Yasuko asks him for clarification, he asks if her husband has used any weapons against her. She replies yes, to which he then asks, “Are you sure?" (本当に?) with a questioning tone (00:51:52). At this point the camera switches from the stationary shot of the two conversing to close-up shots of their faces instead. When the camera is on Yasuko, the discomfort and unease that is afflicting her is clear. Yasuko is hunched with her head bowed down and does not make eye contact with the officer (00:51:55). The tight framing of the close-up shot emphasises Yasuko's feelings of being trapped by her inability to make the officer understand and the self-doubt brought about by the questioning.

The policeman recommends Yasuko to visit a consultation centre because domestic violence can become very serious, and begins to explain the consequences for her husband if the court grants her appeal for protection. As he does so, the camera switches to Yasuko, now with a blurry figure appearing in the background. As the officer expounds about how her poor husband would be kicked out of his home and get a criminal record, the encroaching figure suggests a looming threat as it approaches the station. Gradually, it becomes clear that the figure is Shōgo and the scene begins to take on a horror-like dimension, with a 'monster' bearing down on the female protagonist.

The ineptitude of the police officer is driven home by his juxtaposition with Yasuko after Shōgo arrives. The officer's grin when he greets Shōgo feels inappropriate for the viewer, who has seen the extent of the violence that Shoggo has inflicted upon Yasuko. As the policeman's grinning face turns towards her, the camera follows his gaze and pans to the right, showing Yasuko's hunched figure with sounds of her muffled sobbing audible. The comparison of the two characters emphasises the emotional chasm between victim and institution. Although she found very little assistance, Yasuko's awareness of the sociolegal avenues available to her as a victim of domestic violence reflects the increased recognition of the issue. However, as the film shows, legal reform is merely a single stepping stone to effecting actual change within individuals, communities, and society.

The above analysis has focused on Yasuko as a victim of domestic violence rather than rape, as the film emphasises the physical aspects of domestic abuse over the psychological and sexual aspects. In the public discussion of domestic violence, physical violence tends to dominate the discourse (Pagelow 1988). Although the Japanese government recognises forced sexual activity as 
part of domestic violence, it is not referred to as 'rape' (Kakuchi 2003; AJWRC 2007). By letting physical violence dominate the discourse on spousal abuse in the Japanese legal framework, many victims fall between the cracks as physical violence is not a necessary condition for marital rape to occur (Russell 1982; Finkelhor and Yllo, 1985). Nakahara never explicitly establishes the sexual violence that Yasuko faces as 'rape' within the film. Although Yasuko indicates on a questionnaire that she feels sexual relations with her husband are not normal (夫との SEX は正常である?) (00:00:29), none of the characters call these incidents of unwanted sexual intercourse 'rape'. By not doing so, Nakahara allows the viewer to reach their own understanding of the nature of these acts. Whether the audience interprets these scenes as rape sequences, as I have, will be dependent on the individual viewer's perception on marital rape. The lack of acknowledgement of marital rape in the film reflects how the issue is treated within Japanese society and suggests how residual silence is built up around it, a problem that remains strongly rooted within many contemporary societies. Yet, while marital rape has been largely invisible in terms of public discourse, it has at least been drawn into the conversation through the broader problem of domestic violence.

As has been shown, the inclusion of social commentary within films makes cinema a possible site for communicating issues of social importance. Aside from picking up on deliberately included messages, the viewer can also garner unintended insights into the cultural, social and historical conditions under which the film has been created. Cinema can be a powerful tool for confronting viewers with the social and institutional prejudices faced by rape victimsexperiences that may otherwise be distant to them-and break the silence that keeps these struggles unheard. By focusing on these barriers throughout the cinematic narrative, the viewer is encouraged to reflect upon what they know and think about the realities and injustices of rape for victims.

\section{BECOMING A SURVIVOR: A GLANCE INTO A VICTIM'S PROCESS OF RECOVERY}

In this final section, I return to one of the common criticisms of rape representations: that the victim's recovery story is rarely given attention and the realities of rape trauma are not fully explored. Here, I examine how The Ravine of Goodbye provides one such story, by exploring Natsumi's journey to work through her trauma. By representing rape's lingering effects, the filmmaker portrays the long-term nature of rape recovery-an experience that the victim has been conditioned, through social and cultural norms, to keep secret and hidden from the rest of society. In The Ravine of Goodbye, the protagonist Natsumi is shown confronting her abuser-not an action usually taken by victims of abuse. Confronting the abuser, usually symbolically, is considered an important part of healing and this can be enough for some individuals to recover from abuse. For others, it is a major step in a longer process (Freshwater et al. 2002). In exploring this personal journey, Ōmori creates a stage for the viewer to witness the emotional hardships faced by victims of sexual violence. This allows space for a dialogue between the viewer 
and the film that may facilitate a questioning of the social conditions that have created these barriers for victims.

Natsumi's confrontation with Shunsuke is a reversal of the power dynamics between victim and victimiser. Following the rape, Natsumi is unable to escape from the stigma attached to rape victims. She tries moving on, going through a failed engagement, miscarriage, domestic violence, suicide attempts. By contrast, Shunsuke has a relatively easier life, but is wracked by guilt for his past actions and cannot let go. Years after the incident, during a dinner, one of the other rapists mentions to Shunsuke that he had seen Natsumi at the hospital. Soon after, Shunsuke visits Natsumi, who becomes hysterical upon seeing him. Haunted by his actions, Shunsuke persistently sends letters to Natsumi, which she leaves unopened. Following another suicide attempt, she finally opens a letter and calls him. Shunsuke finds Natsumi sitting in a payphone booth, clutching the letter. She reveals that, in his letters, Shunsuke declares he will do anything for her. She doubts him at first, then realises that his declaration is genuine. From this point, Natsumi begins to test the limits of what Shunsuke will do to atone.

As Natsumi moves from town to town she is followed closely by Shunsuke. Things come to head in the countryside as a fierce confrontation erupts when Shunsuke tries to lend Natsumi his jacket. As the wind rages against them, Natsumi explodes:

No matter what happens, I will never forgive you. If you'd be happier if I died, then I never want to die. If you think you'd be better off dead, then I refuse to let you die. Don't you dare try and get comfortable with this. ${ }^{6}$

$(01: 16: 42)$

The mise-en-scene in this confrontation reflects Natsumi's turbulent emotions. In her shots, the camera's low angle suggests she is bearing down on Shunsuke. The dark lighting and storm clouds in the background emphasise Natsumi's thunderous rage as she unleashes her diatribe onto the silent Shunsuke. The direction of the wind, blowing from Natsumi toward Shunsuke, reinforces the active-passive roles they hold in this outburst and foreshadows the power dynamics of their relationship in the future-Natsumi as the decision-maker and Shunsuke as the passive receiver of her authority.

Following the confrontation, Natsumi begins the process of regaining control over her life by 'becoming' Kanako. At an inn, Natsumi signs in as 'Kanako' in the guest registry. Later, Natsumi explains to Shunsuke:

That night ... the name of the girl that went home. The girl that went home that night was called Kanako. That night, I ... Kanako went home. ${ }^{7}$

(01:19:40)

In 'becoming' Kanako, Natsumi allows herself a momentary escape from being a rape victim. This can be seen as a manifestation of the way that 
traumatised people may create new personalities to "deceive themselves into thinking that their worst traumas happened to 'someone else,' not to them" (Waugaman 2010, 853).

At one point, Natsumi runs off after telling Shunsuke to stop following. After a while, she stops and looks back, finding him no longer behind her. Eventually, he returns and apologises again, to which Natsumi reveals that, upon his absence, she wanted him to return. Upon hearing this, he breaks into uncontrolled sobbing, and the two come to a quiet understanding. Soon after, Shunsuke tells Natsumi that his finances are low and she must decide what happens after this. Renting a small apartment with the remaining money, they begin anew by reinventing themselves as husband and wife.

Peppered throughout the film, from small decisions like buying kitchen cabinets to more crucial ones like the possibility of sending Shunsuke to gaol, Natsumi is given control of the relationship. The most striking way this manifests is through Natsumi's sexual empowerment. Constance Mui (2005) argues that traumatic violence, such as rape, severs the body's unity with the self. For a person to "feel at home in the world, one must first feel at home with one's body" $(2005,160)$. Rape disrupts this oneness by making the victim painfully aware of the body that has betrayed her (2005). To overcome this betrayal, victims often choose to desexualise themselves in order to "regain control of [their] own body boundaries" $(2005,159)$. In their study of the effects of rape on sexual activity, Ann Burgess and Lynda Holmstrom (1979) found that most rape victims do resume sexual activity over time, with one interviewee saying that having sex on her own terms was "like I was saying to myself, 'I'll have an upper hand now"' (652).

In The Ravine of Goodbye, Natsumi's resumption of sexual activity symbolises reclaiming control over her vulnerable body and sense of self. The film begins by showing Kanako and Shunsuke's sexually active relationship, in a sex scene that dominates the first eight minutes. The first time the two engage in sex since the rape is also the last sex scene in the film, appearing as a flashback to the past. At first, Natsumi pushes Shunsuke away, stopping any further advances. When she does eventually allow his advances, Natsumi is both consenting to Shunsuke and also reclaiming control over her own desires. In other scenes, Natsumi is shown as the instigator, and in control of what is permissible. By choosing to become sexually active with the partner of her choice, Natsumi takes back what the rape forcibly took away from her: the control over her body and the choice to act upon her sexual desires.

While acknowledging some of the sensitive, thoughtful elements of the narrative, it is also important to critique the problematic aspects too. For example, Natsumi and Shunsuke's new life as a married couple falls into the previously mentioned cliché of the victim falling in love with her rapist, which provides an unlikely resolution to what is hardly ever resolved in this way, while also reproducing the general apathy towards the normalisation of sexual violence within popular culture. Also, the film presents an isolated story by focusing on Natsumi's individual struggle rather than exploring the 
structural causes that hinder her recovery. There are hints to systemic factors, but these are not the focus of the narrative. Furthermore, the film exemplifies the absence of female directors and screenwriters engaging with the subject of rape in the film industry, as well as the dearth of women working in production. This is not to assume that male filmmakers are unable to deliver responsible representations, nor that representations from female filmmakers are always sensitively done. However, women writing, editing or directing can potentially offer different perspectives and ways of representing women and sexual violence in a male-dominated industry (Mayne 1981; Dowd 2015; Michalik 2015). When writing a female character's struggle with rape, female writers and directors can possibly help to mitigate the mishandling of the subject through nuanced, thoughtful representations that respect the complexities and sensitivities around sexual violence.

Trauma narratives in cinema can provide a space for viewers to consider the painful experiences of working through trauma. By drawing the viewer into these stories, the filmmaker can show the resilience and determination that survivors of gendered violence experience as they work through their pain, as well as break through internalised silences around this issue. Faced with these uncomfortable narratives, the viewer is presented with an opportunity to reflect upon the nature of trauma from sexual abuse and the way that survivors overcome these wounds in silence. Making the story about the victim alone is unlikely to end the problem of sexual violence in society, but a focus on victims' perspectives at least fulfils the demand from feminist critics for stories that do not cast aside the victims.

\section{CONCLUSION}

Cinema is both a source of entertainment and an avenue through which knowledge is developed and disseminated. As such, it is important to cultivate a keen awareness of the influence that fictional representations have in the process of knowledge formation, and how they shape our imaginations and ways of seeing the world. Aware of the mechanisms at play between filmmaker and viewer through the text, an active viewer is able to critically engage with and realise this discursive potential inherent within the cinematic space. Examining the cinematographic style and narrative content used by filmmakers in The Ravine of Goodbye and DV: Domestic Violence, I have argued that representations of rape and rape recovery have the potential to inspire ethical reflection by the viewer regarding rape and rape victims.

The subject of rape representations in popular culture will continue to be a contentious issue in media criticism. Yet, these representations can raise awareness, challenge dominant perceptions and stimulate public discussion. Feminist critics face a difficult conundrum where they fight to end rape in society while having to tolerate representation of sexual violence to generate discourse. My goal is to provide readings that show how rape representations can potentially empower victims and, in turn, the viewer. It is also 
important to recognise that films can perpetuate ideologies that undermine this, creating a paradox. This does not negate the discursive potential in film for bringing about change, but it is essential to call attention to the ways that even well-intended films can reinforce sexist and anti-feminist discourse.

Rape representations have the discursive potential to break the silence which surrounds sexual violence. By avoiding eroticised depictions of rape and emphasising the violent nature of the act, the filmmaker makes it tougher for the viewer to not reflect upon the fact of sexual violence. The contextualisation of a rape scene within a narrative is also significant: depicting shattered lives within social and cultural conditions encourages the viewer to engage in a social critique of dominant attitudes towards rape and sexual violence. By including the victim's recovery, the viewer is shown the traumatic impacts of rape and the long, ongoing process of healing. Ideally, these fictional depictions of rape can further personal introspection, raise public awareness, stimulate dialogue about sexual violence and encourage further participation in activism against sexual violence.

In my analysis of the two chosen films, I have primarily focused on how the filmmaker can elicit reflective responses within the viewer through the cinematic space. There is a need for filmmakers to be aware of the complexities in representing rape. As well, the viewer has a responsibility to decide whether to critically engage with cinematic representations of rape and reflect upon how they feel about the issue. The discussion of fictional depictions in popular culture alone is unlikely to end the silence that continues to keep the actual experiences of both victims and survivors hidden. However, alongside the efforts of Japanese feminists who are breaking the silence and working to change attitudes to sexual violence in Japanese social and legal spheres, I hope to challenge the dominant discourses surrounding sexual violence.

\section{REFERENCES}

Aaron, M. 2007. Spectatorship: The Power of Looking On. London: Wallflower Press.

AJWRC (Asia-Japan Women's Resource Center). 2007. "Executive Summary of 'Violation of Women's Rights in Japan': Alternative Report to the UN Committee Against Torture $38^{\text {th }}$ Session". Voices from Japan 19, 5-10. Accessed 6 February, 2016. http://www.ajwrc.org/english/sub/voice/19-1-2.pdf.

AJWRC (Asia-Japan Women's Resource Center). 2008. "Sexual Violence in Japan: Challenging the Criminal Justice System”. Voices from Japan 21, 14-16. Accessed 20 May, 2016. http://www.ajwrc.org/english/sub/voice/21-1-3.pdf.

Anderson, H. 2007. "A Postmodern Umbrella: Language and Knowledge as Relational and Generative, and Inherently Transforming". In Collaborative Therapy: Relationships and Conversations That Make a Difference, edited by H. Anderson and D. Gehart, 7-19. New York: Routledge.

Arnold, M. 2015. "Sex Every Afternoon: Pink Film and the Body of Pornographic Cinema in Japan". PhD dissertation, University of Michigan. 
Asatori, S. and F. Suzuki. 2009. "Discrimination in the Field of Reproductive and Sexual Rights in Japan". Paper presented at The Convention on the Elimination of All Forms of Discrimination Against Women 44th Session, July 20-August 7.

Buckley, S. 1997. Broken Silence: Voices of Japanese Feminism. Oakland: University of California Press.

Burgess, A. and L. Holmstrom. 1979. "Rape: Sexual Disruption and Recovery". American Journal of Orthopsychiatry 49: 648-57. http://dx.doi.org/10.1111/ j.1939-0025.1979.tb02650.x

Burns, C. 2005. Sexual Violence and the Law in Japan. New York: Routledge.

Campbell, R. 2005. "What Really Happened? A Validation Study of Rape Survivors' Help-Seeking Experiences With the Legal and Medical Systems”. Violence and Victims 20 (1): 55-68. http://dx.doi.org/10.1891/0886-6708.2005.20.1.55

Cartwright, L. 2008. Moral Spectatorship: Technologies of Voice and Affect in Postwar Representations of the Child. Durham: Duke University Press.

Chris, C. 2013. "Queasy Questions About Media Effects". Contexts 12 (3): 60-2. http://dx.doi.org/10.1177/1536504213499881

Cybriwsky, R. 2011. Historical Dictionary of Tokyo. 2nd edition. Lanham: Scarecrow Press.

Dowd, M. 2015. “The Women of Hollywood Speak Out”. New York Times, November 20. Accessed 12 January, 2016. http://www.nytimes.com/2015/11/22/ magazine/the-women-of-hollywood-speak-out.html?_r=0.

Durham, M. 2008. The Lolita Effect. New York: The Overlook Press.

DV: Domestic Violence [DV:ドメスティック・バイオレンス]. 2004. Directed by S. Nakahara [中原 俊]. DVD. Tokyo: Happinet Pictures.

Finkelhor, D. and K. Yllo. 1985. License to Rape: Sexual Abuse of Wives. New York: Holt, Rinehart, \& Winston.

Freshwater, K., C. Ainscough and K. Toon. 2002. "Confronting Abusers: The Opinions of Clinicians and Survivors". Journal of Child Sexual Abuse 11 (4): 35-52. http://dx.doi.org/10.1300/J070v11n04_03

Friedman, J. 2014. Rape on TV-More Than Just a Plot Twist. Accessed 17 July, 2014. http://prospect.org/article/rape-tv\%E2\%80\%94more-just-plot-twist.

Fuentes, M. 2013. "Nonkilling Media from a Gender Perspective". In Nonkilling Media, edited by J. Pim, 173-90. Honolulu and Omaha: Center for Global Nonkilling.

Gender Equality Bureau Cabinet Office [内閣府男女共同参画局]. 2014. “Josei ni taisuru bōryoku' ni kansuru chōsa kenkyū” [男女間における暴力に関する 調査]. Accessed 20 May, 2016. http://www.gender.go.jp/policy/no_violence/ e-vaw/chousa/h26_boryoku_cyousa.html. 
Goerke, C. 2013. Using Rape as a Plot Device. Accessed 17 July, 2014. http://www. feminisms.org/5844/using-rape-as-a-plot-device/.

Halberstam, J. 1993. “Imagined Violence/Queer Violence: Representation, Rage and Resistance”. Social Text 37: 187-201. http://dx.doi.org/10.2307/466268

Hall, S. 1980. "Encoding/Decoding". In Culture, Media, Language, edited by S. Hall, D. Hobson, A. Love and P. Willis, 128-38. London: Hutchinson.

1997. Representation: Cultural Representations and Signifying Practices. London: Sage.

Heller-Nicholas, A. 2011. Rape-revenge Films: A Critical Study. Jefferson: McFarland.

Higgins, L., and B. Silver, eds. 1991. Rape and Representation. New York: Columbia University Press.

Horeck, T. 2004. Public Rape. New York: Routledge.

Hunter, J. 1998. Eros in Hell: Sex, Blood and Madness in Japanese Cinema. London: Creation.

Kaino, T. [戒能 民江]. 2005. “Tokushū 1.4 DV hō seitei kara kaisei e: sono igi to kadai” [特集1.4 DV 法制定から改正へ—その意義と課題]. Kokusai Josei [国際女性] 19: $76-84$.

2010. "Domesutikku baiorensu bōshihō to josei ni taisuru bōryoku bōshi e no kadai” [ドメスティック・バイオレンス防止法と女性に対する暴力防止一の課 題]. Masse Osaka Kenkyū Kiyō [マッセ Osaka 研究紀要] 5: 15-24.

Kakuchi, S. 2003. "Japan's Battlers of Sex Abuse Confront Culture, Law". Women's Enews, April 17. Accessed 6 February, 2016. www.feminist.com/news/ news187.html.

Konishi, T. [小西 隆子]. 2009. Hanzai higaisha no kokoro no kizu [犯罪被害者の心の 傷]. Tokyo: Hakusuisha [白水社].

Koopman, E. 2010. "Reading Rape: Toward an Ethics of Responding to Literary Depictions of Suffering and Violence". Masters thesis, Utrecht University.

Linz, D., E. Donnerstein and S. Penrod. 1984. "The Effects of Multiple Exposures to Filmed Violence Against Women". Journal of Communication 34 (3): 130 47. http://dx.doi.org/10.1111/j.1460-2466.1984.tb02180.x

Mayne, J. 1981. "The Woman at the Keyhole: Women's Cinema and Feminist Criticism”. New German Critique 23:27-43. http://dx.doi.org/10.2307/487935

McLelland, M. 2005. Queer Japan from the Pacific War to the Internet Age. Lanham: Rowman \& Littlefield.

Michalik, Y. 2015. "Indonesian Women Filmmakers: Creating a New Female Identity?". Indonesia and the Malay World 43 (127): 378-96. http://dx.doi. org/10.1080/13639811.2015.1054139 
Mui, C. 2005. "A Feminist-Sartrean Approach to Understanding Rape Trauma". Sartre Studies International 11: 153-165. http://dx.doi.org/10.3167/1357155 05780282588

Mulvey, L. 1989. Visual and Other Pleasures. Indianapolis: Indiana University Press.

Myrick, T. 2014. "The Horror of Sexual Violence: The Representation of Rape in American Horror Story". Honours thesis, University of Utah.

Iijima, Y. [飯島 裕子]. 2012. “'Intabyū' Nakahara Shun-kantoku 'Kore ha DV? Sore tomo ai? Eiga no naka de sagashitemoraitai” [「インタビュー] 中原俊監督「れれ はDV? それとも愛? 映画の中で探してもらいたい]. The Big Issue Japan [ビッ グイシュー日本版]. Accessed 19 August, 2014. http://bigissue-online.jp/2012/ 10/09/interview/.

Niwa, M. 2004. "Why Violence is Directed towards Girls". Voices from Japan 12: 1-3. Accessed 14 October, 2014. http://www.ajwrc.org/english/sub/voice/12-1-1. pdf.

NPA (National Police Agency) [警察庁]. 2016. Hanzai tōkei shiryō [犯罪統計 資料]. Accessed February 1, 2016. http://www.e-stat.go.jp/SG1/estat/List.do ?bid $=000001066458 \&$ cycode $=0$.

Omori, K., Y. Zhang, M. Allen, H. Ota and M. Imamura. 2011. "Japanese College Students' Media Exposure to Sexually Explicit Materials, Perceptions of Women, and Sexually Permissive Attitudes". Journal of Intercultural Communication Research 40 (2): 93-110. http://dx.doi.org/10.1080/17475759 .2011 .581031

Pagelow, M. 1988. "Marital Rape". In Handbook of Family Violence, edited by V. van Hasselt, R. Morrison, A. Bellack, and M. Hersen, 207-30. New York: Plenum Press.

Phillips, J. 2016. "Confrontational Content, Gendered Gazes and the Ethics of Adaptation in Outlander and Game of Thrones". In Adoring Outlander: Essays on Fandom, Genre and the Female Audience, edited by V. Frankel, 162-81. Jefferson: McFarland.

Projansky, S. 2001. Watching Rape: Film and Television in Postfeminist Culture. New York: NYU Press.

Rodriguez, A. 2014. "Rape Culture, Trigger Warnings, and 'Bates Motel”'. Accessed 17 July, 2014. http://www.btchflcks.com/2014/02/rape-culture-trigger-warn ings-bates-motel.html.

Russell, D. 1982. Rape in Marriage. New York: Macmillan Press.

Shibata, T. 2008. "Pornography: Sexual Objectification and Sexual Violence in Japan and in the World". Working Paper, Centre for East and South-East Asian Studies, Lund University. Accessed 21 June, 2016. https://lup.lub.lu.se/ search/publication/3128514. 
Shin, K. 2011. “The Women's Movements”. In Routledge Handbook of Japanese Politics, edited by A. Gaunder, 175-86. New York: Routledge.

Smith, M. 2004. Encyclopedia of Rape. Westport: Greenwood Press.

Sontag, S. 2003. Regarding the Pain of Others. London: Penguin.

The Ravine of Goodbye [さよなら渓谷]. 2013. Directed by T. Ōmori [大森 立嗣]. DVD. Tokyo: Stardust Pictures.

Tsunoda, Y. 1995. "Japanese Women Confront Domestic Violence”. The Journal of the International Institute 3 (1): 7-17. Accessed 14 October, 2014. http://hdl. handle.net/2027/spo.4750978.0003.104

Viteo, K. 2012. "Day of the Woman?: Feminism \& Rape-Revenge Films". Masters thesis, University of Western Ontario.

Waugaman, R. 2010. "Samuel Clemens and Mark Twain: Pseudonym as Act of Reparation”. Psychoanalytic Review 97 (5): 835-856. http://dx.doi. org/10.1521/prev.2010.97.5.835

Wilson, L. 2012. "Physical Spectatorship: Noise and Rape in Irreversible". In Reverberations: The Philosophy, Aesthetics and Politics of Noise, edited by M. Goddard, B. Halligan and P. Hegarty, 121-32. London: Continuum.

Yatagawa, T. and M. Nakano. 2008. "Sexual Violence and the Japanese Criminal Judicial System”. Voices from Japan 12: 4-13. Accessed 14 October, 2014. http://www.ajwrc.org/english/sub/voice/21-1-2.pdf.

Zillman, D. and J. Bryant. 1984. "Effects of Massive Exposure to Pornography". In Pornography and Sexual Aggression, edited by N. Malamuth and E. Donnerstein, 115-41. Orlando: Academic Press. 